\title{
PENDIDIKAN ETIKA UNTUK ANAK JALANAN DI KOTA MADIUN
}

\author{
Mamik Sumarmi (mamiksumarmi@ut.ac.id) \\ Sulistiyono \\ Universitas Terbuka
}

\begin{abstract}
The aim of inventory the factors of street children and identify appropriate handling by ethics education. Survey method of data collecting technique is by questioner and limited interview. Data were analyzed by descriptive qualitative. The result showed that the dominant factor of street children are economic and parental education low levels and their job street musician, construction waiter, pedicab driver and casual laborers. Right now street children work as the rental canvas shelters, deliverying drink and foods singing in door to door in their vilages, and in the bus. Their income per day is about Rp20.000 just for their need, such as, to pay the play station, buy cigarettes, eat, and alcohols drink. Based on the result of the study showed that $100 \%$ of street children agree to behave good ethics, such as, maintain their good health, maintain their ethics in the street, when they work, execute commands with good faith, instill their self confidence, avoid malicious behavior, stealing, hurting others, and fight.
\end{abstract}

Keywords: educational ethics, street children

\begin{abstract}
ABSTRAK
Tujuan penelitian ini adalah menginventarisasi faktor adanya anak jalanan (anjal) dan mengidentifikasi bentuk penanganannya melalui pendidikan etika. Metodenya survei, teknik pengumpulan data dengan angket dan wawancara terbatas. Data dianalisis secara deskriptif kualitatif. Hasil penelitian menunjukkan bahwa faktor dominan adanya anak jalanan adalah faktor ekonomi dan pendidikan orang tua yang rendah, pekerjaannya sebagai pengamen, kuli bangunan, tukang becak dan pekerja serabutan. Sekarang, anak jalanan ada yang bekerja di persewaan terop, mengantarkan makanan itik, mengamen di kampung dan di bus. Penghasilan sekitar Rp.20.000 per hari untuk kebutuhan sendiri, seperti; biaya main playstation, membeli rokok, membeli miras, dan makan. Penanganan dengan pengarahan, mengisi angket. Hasilnya 100\% anjal setuju melakukan etika yang baik misalnya menjaga kesehatan, etika waktu mengamen, waktu di jalan, waktu di tempat kerja, dan yang berkaitan dengan agama menanamkan kepercayaan diri menghindari perilaku jahat, mencuri, menyakiti orang lain, dan berkelahi.
\end{abstract}

Kata kunci: anak jalanan, pendidikan etika.

Anak, sering kali dipersepsikan sebagai manusia yang masih berada pada tahap perkembangan sehingga belum dapat dikatakan sebagai manusia yang utuh. Dengan keterbatasan usia yang tentunya berpengaruh pada pola pikir dan tindakan, anak belum mampu memilah antara hal yang baik dan buruk. Oleh sebab itu, pengawasan ekstra terhadap anak secara pribadi mau sebagai bagian dari masyarakat perlu dilakukan perlindungan hak-hak anak dan serta mencegah 
masuknya pengaruh eksternal negatif yang dapat mengganggu tumbuh kembangnya anak. Salah satu bentuk tanggung jawab pemerintah dalam hal melindungi anak bangsa adalah dengan memberikan suatu perlindungan hukum bagi anak.

Hak dan kewajiban anak diatur dalam Undang-undang Nomor 23 tahun 2002 pasal 4 hingga pasal 19 tentang Perlindungan Anak. Dalam Undang-undang tersebut, pasal 4-18 tentang hak anak, pasal 19 tentang kewajiban anak. Adapun hak anak antara lain beribadah menurut agamanya, mendapatkan pelayanan kesehatan, memperoleh pendidikan dan pengajaran, mengutarakan pendapatnya sesuai tingkat kecerdasan dan usianya, memanfaatkan waktu luang untuk bergaul dengan anak sebayanya, bermain, berekreasi sesuai minat, bakat dan tingkat kecerdasannya dalam rangka mengembangkan diri. Kewajiban anak yang tercantum dalam Undang-undang Nomor 23 tahun 2002 pada pasal 19 yaitu: (a) menghormati orang tua, wali, dan guru; (b) mencintai keluarga, masyarakat, dan menyayangi teman, (c) mencintai tanah air, bangsa, dan negara, (d) menunaikan ibadah sesuai dengan ajaran agamanya, dan (e) melaksanakan etika dan akhlak yang mulia.

Dengan diaturnya hak dan kewajiban anak dalam sebuah undang-undang, pemerintah menaruh harapan bahwa negara, keluarga, dan masyarakat mengetahui dan melaksanakan sesuai dengan apa yang telah diatur. Namun anak sering kali hidup, tumbuh dan berkembang tanpa diperhatikan pemenuhan terhadap segala hal yang menjadi haknya oleh orangtuanya. Banyak anak putus sekolah, dipaksa bekerja untuk membantu mengurangi beban hidup orang dewasa/orangtua dan keluarga. Mereka kehilangan waktu untuk bergaul atau bermain dengan anak sebayanya. Artinya perhatian serta penerapan Konvensi Hak Anak (KHA) dan Undang-Undang Perlindungan Anak belum terealisasi dengan baik.

Anak-anak yang putus sekolah ini bekerja membantu keluarganya atau dieksploitasi orang lain untuk mendapatkan uang di jalanan. Anak ini disebut anak jalanan (anjal) yang kegiatan seharihari di jalan berupa ngamen dan minta-minta. Mereka di jalanan tidak kenal waktu, bahkan tidurpun ada yang di pinggir jalan. Hal ini kalau dibiarkan lama-lama akan membuat kesan negatif bagi masyarakat maupun pemerintah setempat. Dengan kesibukannya setiap hari asal mendapatkan uang dengan seenaknya sendiri, anak tersebut akan lupa dengan kewajibannya sebagai seorang anak. Mereka ramai-ramai bergabung dengan teman-teman sesama anak jalanan tanpa beban apapun.

Menurut Suyanto (2003) bahwa untuk bertahan hidup di tengah kehidupan kota yang keras, anak-anak jalanan biasanya melakukan berbagai pekerjaan di sektor informal, baik yang legal maupun yang ilegal di mata hukum. Ada yang bekerja sebagai pedagang asongan di kereta api dan bus, menjajakan koran, menyemir sepatu, mencari barang bekas atau sampah, mengamen di perempatan lampu merah, tukang lap mobil, dan tidak jarang pula ada anak-anak jalanan yang terlibat pada jenis pekerjaan berbau kriminal seperti mencuri, bahkan menjadi bagian dari komplotan perampok.

Sebagian anak jalanan bertahan hidup dengan cara yang kurang dapat diterima oleh masyarakat. Menurut Mohammad Farid (dalam Suyanto, 2003) bahwa tantangan kehidupan yang mereka hadapi pada umumnya memang berbeda dengan kehidupan normatif yang ada di masyarakat dan dalam banyak kasus, anak jalanan sering hidup dan berkembang di bawah tekanan dan stigma atau cap sebagai pengganggu ketertiban. Selanjutnya dijelaskan bahwa perilaku mereka sebenarnya merupakan konsekuensi logis dari stigma sosial dan keterasingan mereka dalam masyarakat. Tidak ada yang berpihak kepada mereka, dan justru perilaku mereka sebenarnya mencerminkan cara masyarakat memperlakukannya. 
Kehadiran anak-anak yang kurang beruntung ini, perlu diberdayakan dengan sentuhan lembut penuh kasih sayang dan kemanusiaan. Namun, berkembangnya sikap latah dan sombong ingin bergaya hidup feodal secara instan, agaknya telah membakar dan menghanguskan nilai-nilai kemanusiaan. Gaya hidup borjuis dan feodalistik itu, disadari atau tidak, justru telah memosisikan anak-anak jalanan makin kehilangan kesejatian dirinya. Kata-kata kasar dan perlakuan tak senonoh sudah menjadi hiasan hidup keseharian anak jalanan. Orang-orang kaya yang seharusnya bisa menggerakkan semangat hidup anak-anak jalanan ini, justru makin menjauhi dan membencinya.

Ada beberapa penelitian yang telah dilakukan terhadap anak jalanan, misalnya Penelitian oleh Dwi Astutik (Tesis) tahun 2003 dengan judul "Pengembangan Model Pembinaan Anak Jalanan Melalui Rumah Singgah di Jawa Timur". Penelitian ini mengambil sampel 3 kota yaitu Surabaya, Sidoardjo dan Malang. Adapun yang mewakili rumah singgah sebanyak 7 rumah singgah dari 40 rumah singgah di Jawa Timur. Hasil penelitian menyebutkan bahwa model pembinaan yang tepat bagi anak jalanan melalui rumah singgah adalah dengan menggunakan analisis SWOT. Kekuatan dan kelemahan dari faktor intern baik dari anak jalanan maupun dari rumah singgah serta peluang dan ancaman/tantangan dari faktor extern yaitu dari unsur instansi pemerintah terkait, dunia usaha, media dan masyarakat dengan menggali serta memadukan kebutuhan dan harapan anak jalanan. Lebih rinci, baik profil anak jalanan, kapasitas, fasilitas layanan serta manajemen yang baik dari rumah singgah patut dijadikan bahan pertimbangan dalam mencari model pembinaan yang tepat bagi sasaran.

Penelitian lain dilakukan oleh Wahyuni (Tesis) tahun 2008 dengan judul "Teori KeberhasilanKegagalan Pendampingan Anak Jalanan". Temuan yang diperoleh dari penelitian ini adalah sebuah teori keberhasilan-kegagalan pendampingan anak jalanan yang mengatakan bahwa keberhasilankegagalan pendampingan anak jalanan sangat ditentukan oleh mindset anak jalanan. Pendampingan anak jalanan akan berhasil apabila mampu mengubah mindset (pola berpikir yang mempengaruhi tingkah laku) anak jalanan dari yang negatif menjadi positif. Anak jalanan yang merasa dirinya tidak mampu, merasa dirinya tidak berharga, merasa dirinya tidak pantas bercita-cita, dan merasa bebas tidak punya tanggungan, menjadi anak yang merasa dirinya mampu, merasa dirinya mempunyai hari esok, dan merasa dirinya mempunyai tanggungan yang harus ditunaikan. Konstruksi teori tersebut dapat disimpulkan dalam satu konsep yang dapat menjelaskan fenomena keberhasilan-kegagalan pendampingan, yaitu "mindset revolusioner" yang berarti bahwa pendampingan anak jalanan akan memperoleh keberhasilan apabila mampu menyentuh dan mengubah mindset anak jalanan. Sebaliknya pendampingan anak jalanan akan mengalami kegagalan apabila hanya mementingkan hal-hal yang bersifat hardskill tanpa menyentuh dan mengubah mindset anak jalanan itu sendiri.

Selanjutnya penelitian Sigit Bayu Laksono (Skripsi) dengan judul "Peran Dinas Sosial dan Tenaga Kerja dalam Pemberdayaan Anak Jalanan di Kecamatan Sidoarjo, Jawa Timur tahun 2011. Hasil penelitian menyebutkan bahwa hasil razia anak jalanan yang dilakukan oleh Satpol PP, Kepolisian, dan Dinas Kesejahteraan Sosial Kabupaten Sidoardjo mayoritas berasal dari Kabupaten Sidoardjo sebanyak 14 atau sebesar 82,35\%. Setelah diregistrasi, anak tersebut ditangani langsung oleh Dinas Kesejahteraan Sosial Kabupaten Sidoardjo, kemudian dibina melalui bimbingan sosial dan pembinaan keterampilan kerja sesuai dengan bakat dan kemampuan yang dimiliki oleh anak jalanan. Selanjutnya Dinas Sosial melakukan pengawasan dan evaluasi terhadap pelatihan dan pembinaan dari berbagai kegiatan yang diikuti dengan harapan nantinya mereka dapat berpartisipasi dalam pembangunan kesejahteraan sosial.

Dari tiga peneliti yang telah dilakukan di Surabaya, Sidoardjo dan Kabupaten Malang dapat disimpulkan bahwa penanganan anak jalanan perlu dilakukan secara serius. Kerja sama dengan 
beberapa instansi pemerintah maupun swasta serta dukungan masyarakat yang penuh keikhlasan, kasih sayang dan kemanusiaan agar anak-anak bangsa berkembang secara wajar dan menjadi generasi penerus yang tangguh sangat diperlukan.

Jumlah anak jalanan di Jawa Timur sampai sekarang belum dapat dipastikan karena belum tersedianya data base tentang anak jalanan yang akurat. Selain itu, meski telah ada perundangan yang terkait dengan pendidikan, kesejahteraan, perlindungan dan kekerasan anak jalanan (dalam kerangka Undang-undang Perlindungan Anak), namun penegakannya belum efektif, serta belum tersosialisasi dengan baik. Kebijakan penanganan anak jalanan masih belum didukung dengan sumber daya yang memadai, baik berupa fasilitas, sumber daya manusia maupun pendanaan. Hal ini menunjukkan dampak dari pembangunan yang belum memihak pada orang miskin.

Anak jalanan kini telah menyebar di setiap penjuru kota termasuk kota Madiun. Anak-anak jalanan ini mengamen dan meminta-minta di perempatan jalan, pertokoan, pasar, dan ada pula yang mengamen ke rumah-rumah. Mereka berbekal gitar kecil atau alat ecek-ecek, ada yang sendirian dan ada yang rombongan dua anak atau lebih.

Pemerintah Daerah setempat telah melarang dan menertibkan keberadaan anak-anak jalanan ini. Namun masih tetap ada dan berkeliaran di perempatan jalan maupun ngamen ke rumahrumah. Oleh sebab itu, anak-anak jalanan di Kota Madiun perlu diteliti agar mendapatkan masukan bagaimana solusinya, karena anak-anak tersebut mestinya harus sekolah dan belum waktunya mencari nafkah. Selain itu, mereka mengganggu lalu lintas di perempatan jalan serta mengkhawatirkan keselamatannya.

Selain mengkhawatirkan kesalamatannya, masa anak-anak sangat membutuhkan perhatian dari orangtua, sekolah dan pemerintah agar perkembangan anak, baik pisik maupun psikis berjalan normal. Orang tua harus memberikan kasih sayang dan mencukupi nutrisi yang bagus serta menyediakan fasilitas kegiatan sesuai kebutuhan jasmani dan rohaninya. Anak perlu dibimbing, dinasehati, diberi contoh-contoh yang baik, dipuji dan disanjung untuk membesarkan hatinya agar menjadi anak yang terampil, cerdas dan beriman.

Harapan yang ideal itu tidak semua menjadi kenyataan karena adanya beberapa kendala, misalnya faktor ekonomi, sosial dan lingkungan sehingga ada anak yang rajin masuk sekolah, ada yang kadang-kadang sekolah, kadang-kadang tidak dapat masuk sekolah, bahkan ada yang malas tidak mau sekolah. Anak-anak usia sekolah yang kurang beruntung ini pada umumnya menjadi anak jalanan.

Semakin marak anak-anak jalanan di berbagai tempat di kota Madiun seperti di terminal, stasiun kereta api, pasar, pertokoan, berkeliling ke rumah-rumah, di perempatan jalan, membuat masyarakat merasa terganggu dan kurang nyaman. Permasalahan yang sering ditunjukkan oleh anak-anak jalanan di berbagai tempat tersebut dapat berupa mencuri, menjambret, mengganggu lalu lintas, mencoret mobil. Permasalahan yang ditimbulkan oleh anak-anak jalanan tersebut membuat masyarakat merasa terganggu, kurang nyaman, takut, khawatir akan keamanan lingkungan.

Berdasarkan pada uraian dalam identifikasi masalah dapat dipahami bahwa banyak anakanak jalanan yang berasal dari berbagai daerah yang memiliki ragam budaya dalam kehidupannya. Hal ini mengakibatkan anak jalanan cenderung mengikuti perilaku negatif misalnya pemalas, suka mencuri, merampas milik orang lain, berkelahi, mengganggu keamanan dan tidak mempunyai tata krama. Beberapa cara penanganan telah dilakukan di antaranya pelarangan oleh pemerintah daerah khususnya Dinas Sosial dan Satpol PP Kota Madiun. Anak-anak jalanan ini sudah ditangani oleh pemerintah daerah khususnya Dinas Sosial bekerja sama dengan Satpol PP. Pelarangan tersebut ditindaklanjuti dengan merazia anak-anak jalanan di perempatan jalan dan di data identitasnya 
selanjutnya dikembalikan pada orang tuanya. Tetapi yang terjadi anak jalanan tersebut kembali lagi sebagai anak jalanan. Oleh sebab itu, dalam penelitian ini peneliti memfokuskan penelitian terhadap penanganan anak-anak jalanan yang beroperasi di perempatan-perempatan jalan di Kota Madiun yang berdomisili di Kota Madiun melalui perlakuan pendidikan etika.

Berdasarkan uraian pada latar belakang masalah dan batasan masalah di atas, maka rumusan masalah dalam penelitian ini adalah sebagai berikut. Faktor-faktor apa saja yang menyebabkan banyaknya anak jalanan di Kota Madiun? Bagaimanakah bentuk penanganan anak jalanan melalui pendidikan etika di Kota Madiun?

Tujuan penelitian ini adalah untuk menginventarisasi faktor-faktor yang menyebabkan banyaknya anak jalanan di Kota Madiun dan mendeskripsikan bentuk penanganan anak jalanan melalui pendidikan etika di Kota Madiun.

\section{KAJIAN PUSTAKA}

\section{Anak Jalanan}

Anak jalanan sering disingkat Anjal, adalah istilah umum yang mengacu pada anak-anak yang mempunyai kegiatan ekonomi di jalanan, namun masih memiliki hubungan dengan keluarganya. Berdasarkan Undang-Undang Perlindungan Anak, yang dimaksud dengan anak adalah seseorang yang belum berusia 18 tahun rata-rata umurnya antara 5-18 tahun. Ada lagi yang berpendapat bahwa anak jalanan sebagai anak yang kehidupan ekonominya lebih cenderung di jalanan. Sebagian dari mereka mungkin masih mempunyai keluarga, dan sebagian lagi sudah tidak mempunyai keluarga. Biasanya mereka yang masih mempunyai keluarga memilih hidup di jalanan karena broken home yang artinya mereka memiliki keluarga tetapi berantakan, mungkin orangtuanya bercerai, faktor ekonomi yang lemah, dan lain-lain yang menyebabkan mereka lebih senang hidup di jalanan yang bebas tanpa aturan. Mereka yang tidak memiliki keluarga, lebih cenderung karena faktor ekonominya, mereka tidak bisa memenuhi kebutuhan sandang, pangan dan papan, terpaksa harus melakukan kegiatan mengemis, mengamen dan harus hidup di jalanan misalnya tidur di kolong jembatan, teras pertokoan dan sebagainya.

Dari beberapa pendapat tentang anak jalanan tersebut dapat disimpulkan bahwa anak jalanan adalah anak yang kegiatan sehari-harinya mengamen dan mengemis serta tidur di jalanan. Ada beberapa kelompok anak jalanan. Pertama: anak-anak yang masih memiliki keluarga. Mereka melakukan kegiatan ekonomi di jalanan, tetapi masih berhubungan dengan keluarga dan senantiasa pulang setiap hari atau secara berkala. Kedua: anak-anak yang ada di jalanan yang tidak memiliki keluarga atau yang sengaja memutuskan hubungan dengan keluarga dan memilih hidup di jalanan. Ketiga: anak-anak dari keluarga yang ada di jalanan yang menghabiskan seluruh waktunya di jalanan bersama keluarganya yang hidup di jalanan. Keempat: anak berusia 5-17 tahun yang rentan bekerja di jalanan, dan/atau yang bekerja dan hidup di jalanan yang menghabiskan sebagian besar waktunya untuk melakukan kegiatan hidup sehari-hari.

Tabel 1. Kelompok Anak Jalanan

\begin{tabular}{llll}
\hline Groupings of Street Cidren & Percent & $\begin{array}{l}\text { Programme Approahes/ } \\
\text { Strategies }\end{array}$ & $\begin{array}{l}\text { Focus of } \\
\text { Intervention }\end{array}$ \\
\hline $\begin{array}{l}\text { Children who maintain regular contacts } \\
\text { with their families }\end{array}$ & Approximately 70\% & Community-based & Prevention \\
$\begin{array}{l}\text { Children with irreguler contacts with } \\
\text { their families } \\
\begin{array}{l}\text { Children without families/abandoned } \\
\text { children }\end{array}\end{array}$ & Approxi-mately 25\% & Street-based & Protection \\
\hline
\end{tabular}


Berbeda dengan laporan hasil Konferensi Asia, 1989, bahwa kelompok anak jalanan dapat terbagi menjadi 3 kelompok seperti pada Tabel 1.

\section{Pengertian Etika}

Menurut Bertens (1993) bahwa Etika berasal dari bahasa Yunani kuno "ethos" mempunyai banyak arti: tempat tinggal yang biasa, padang rumput, kandang, kebiasaan, adat, akhlak, watak, perasaan, sikap, cara berpikir. Dalam bentuk jamak artinya adalah adat kebiasaan, arti ini yang menjadi latar belakang bagi terbentuknya istilah etika yang oleh filsuf besar Yunani, Aristoteles (384322 S.M.) sudah dipakai untuk menunjukkan filsafat moral. Berdasarkan asal-usul kata etika tersebut, maka etika berarti ilmu tentang adat kebiasaan.

Adapun kata yang cukup dekat dengan etika menurut Bertens (1993) adalah moral yang juga berasal dari bahasa latin mos yang berarti kebiasaan, adat. Jadi etimologi kata "etika" sama dengan etimologi kata "moral" yang sama-sama artinya adat kebiasaan.

Dalam kamus besar Bahasa Indonesia disebutkan tiga arti etika 1) ilmu tentang apa yag baik dan apa yang buruk dan tentang hak dan kewajiban moral (akhlak), 2) kumpulan asas atau nilai yang berkenaan dengan akhlak, 3) nilai mengenai benar dan salah.yang dianut suatu golongan atau masyarakat.

Dari kedua pengertian tersebut dapat disimpulkan bahwa etika merupakan kumpulan asas atau nilai dan norma yang menjadi pegangan bagi seseorang atau suatu kelompok dalam mengatur tingkah lakunya.. Adapun penjelasannya sebagai berikut: 1) Etika Deskriptif, melukiskan tingkah laku moral dalam arti luas, misalnya adat kebiasaan, anggapan-anggapan tentang baik dan buruk, tindakan-tindakan yang diperbolehkan atau tidak diperbolehkan. Etika deskriptif mempelajari moralitas yang terdapat pada individu- individu tertentu dalam kebudayaan atau subkultur tertentu dalam suatu periode sejarah dan sebagainya. Karena etika deskriptif hanya melukiskan, tidak memberi penilaian. 2) Etika normatif, merupakan bagian terpenting dari etika di mana berlangsung diskusi-diskusi yang paling menarik tentang masalah-masalah moral. Di sini ahli bersangkutan tidak bertindak sebagai penonton, netral, tetapi melibatkan diri dengan mengemukakan penilaian tentang perilaku manusia. Misalnya menolak protituasi sebagai suatu lembaga yang bertentangan dengan martabat wanita, walaupun dalam praktek belum tentu dapat diberantas sampai tuntas. Penilaian itu dibentuk atas dasar norma-norma." Martabat manusia harus dihormati" dapat dianggap sebagai contoh tentang norma semacam itu. 3) Metaetika, awalan meta (dari bahasa Yunani) mempunyai arti melebihi, melampaui. Yang dibahas di sini ucapan-ucapan kita di bidang moralitas, pada taraf bahasa etis, atau bahasa yang kita pergunakan di bidang moral. Jadi metaetika mempelajari logika khusus dari ucapan-ucapan etis.

Pendapat lain tentang pengertian etika dari Keraf (1998) menyatakan dua pendapat, pertama bahwa etika sama dengan moral, masing-masing berasal dari kata Yunani "ethos" dan moral dari bahasa latin "mos" mempunyai arti adat istiadat atau kebiasaan. Kedua menyatakan bahwa etika tidak sama dengan moral. Etika mempunyai pengertian lebih luas, sebagai filsafat moral tidak langsung memberi perintah konkret sebagai pegangan siap pakai. Etika sangat menekankan pendekatan kritis dan rasional dalam melihat nilai dan norma moral yang timbul dalam kehidupan manusia di masyarakat mengenai nilai dan norma yang menyangkut bagaimana manusia harus hidup baik sebagai manusia dan mengenai masalah-masalah kehidupan manusia dengan mendasarkan diri pada nilai dan norma- norma moral yang umum diterima.

Pendapat-pendapat tentang pengertian etika tersebut dapat disimpulkan bahwa etika sama dengan moral yang artinya adat, kebiasaan. Jadi dengan kebiasaan atau etika, manusia dapat 
membedakan di antara perilaku yang baik dan perilaku yang tidak baik dalam kehidupan bermasyarakat.

\section{Pentingnya Pendidikan Etika}

Di Kota Madiun terdapat rumah singgah untuk anak jalanan yang terletak di Kecamatan Taman, namun rumah singgah tersebut belum dimanfaatkan maksimal karena belum ada keseriusan dan teralokasinya dana pemerintah setempat untuk menangani anak jalanan yang berada di Kota Madiun.

LSM pernah mengumpulkan anak jalanan pada waktu bulan puasa, mereka diajak buka bersama bagi yang berpuasa, dan makan ala kadarnya termasuk anak yang tidak berpuasa. Mereka diberi nasehat sebentar dan setelah itu kurang terurus, ada yang tidur di rumah singgah, ada yang pulang ke rumah masing-masing.

Bertens (1993) menjelaskan bahwa setiap masyarakat mengenal nilai-nilai dan norma-norma etis. Dalam masyarakat yang homogen dan agak tertutup, masyarakat tradisional, nilai-nilai dan norma-norma itu praktis tidak pernah dibicarakan. Secara otomatis orang menerima nilai dan norma yang berlaku dan tidak berpikir terlalu jauh. Sumber nilai dan norma yang paling penting adalah agama, sedangkan kebudayaan dan nasionalisme atau kerangka hidup bersama dalam satu negara merupakan sumber yang lain.

Sekarang masyarakat tradisional hampir tidak ada, tidak terdapat lagi masyarakat yang homogen dan tertutup. Bertens (1993) juga membedakan situasi etis dalam dunia modern ada tiga ciri yang menonjol, yaitu pertama pluralisme moral, kedua masalah etis baru yang dulu tidak terduga, dan ketiga kepedulian etis yang universal. Adapun penjelasannya masing-masing sebagai berikut: (1) Pluralisme, ditandai dengan kehidupan media komunikasi modern, informasi dari seluruh dunia langsung memasuki rumah-rumah kita, sebagaimana kejadian-kejadian di dalam masyarakat kita segera tersiar ke segala pelosok dunia dengan kehadiran internet. Suka atau tidak suka bersama menerima informasi sebanyak itu kita berkenalan pula dengan norma dan nilai dari masyarakat lain yang tidak selalu sejalan dengan norma dan nilai yang dianut dalam masyarakat kita sendiri. Kemajemukan nilai dan norma dalam praktek bisnis, seksualitas, bahkan terjadi masyarakat yang lebih bebas hubungan seksualitas sebelum perkawinan, hubungan homoseksual, pornografi dan sebagainya, (2) Timbulnya masalah-masalah etis baru yang disebabkan perkembangan pesat dalam ilmu pengetahuan dan teknologi, khususnya ilmu-ilmu biomedis. Misalnya manipulasi genetis, khususnya manipulasi dengan gen-gen manusia, tentang reproduksi, (3) Kepedulian etis yang tampak di seluruh dunia dengan melewati perbatasan negara. Globalisasi tidak hanya di bidang ekonomi, tapi juga di bidang moral.

Melalui bimbingan moral yang baik, anak jalanan diharapkan dapat menjadi orang yang baik pula, syukur dia menjadi contoh yang baik bagi keluarganya, sadar akan pentingnya sekolah dan orang tuanya sadar akan pentingnya bekerja mencari nafkah untuk kehidupan keluarganya. Dengan kesadaran moral tidak ada lagi anak-anak jalanan yang membuat kurang nyamannya pandangan di masyarakat. Hal ini sesuai dengan pendapat Sigmun Freud (1856-1936) dalam Franz MagnisSuseno (2000) bahwa kesadaran moral seseorang berkembang dalam proses penyesuaian dorongan-dorongan instinngtualnya pada realitas hidup bersama dalam masyarakat. Anak kecil belajar bahwa lingkungan sosial terutama ayah dan ibu, tidak mengizinkan segala macam kelakuannya, lama kelamaan anak membatinkan larangan-larangan dan tuntutan-tuntutan lingkungan sosialnya, itulah disebut kesadaran moral. Masyarakat sendiri merumuskan harapan dan 
tuntutannya dalam suatu sistem larangan dan kewajiban dalam norma-norma moral. Dengan belajar mengakui dan bersikap wajar terhadap sistem norma-norma itu seseorag menjadi dewasa.

Keraf (1998) mengatakan bahwa dengan etika pada akhirnya mengharapkan agar orang bertindak sesuai dengan nilai dan norma moral yang berlaku, tetapi kesesuaian itu bukan sematamata karena tindakan yang baik itu diperintahkan oleh moralitas (oleh nenek moyang, oleh orang tua, oleh guru, bahkan oleh Tuhan), melainkan karena ia sendiri tahu dan sadar bahwa hal itu memang baik bagi dirinya dan baik bagi orang lain. la sadar secara kritis dan rasional bahwa ia sepantasnya bertindak seperti itu. Atau sebaliknya, kalau ia akhirnya bertindak tidak sesuai dengan nilai dan norma moral tertentu, itu dilakukan karena alasan-alasan tertentu yang dapat dipertanggungjawabkan secara moral dan bukan karena sekedar ikut-ikutan atau ada maksud lainnya. Jadi etika menghimbau orang untuk memiliki moralitas tuan dan bukan moralitas hamba.

Anak-anak jalanan yang tidak termasuk dalam bidang kehidupan, tetapi kenyataannya ada, maka mereka perlu diberi wawasan tentang etika yang disebut etika terapan atau etika khusus, agar kehidupannya lebih baik. Keraf (1998) membagi etika khusus ini menjadi tiga macam yaitu: (1) etika individual adalah menyangkut kewajiban dan sikap manusia terhadap dirinya sendiri, salah satu prinsip yang secara khusus relevan dalam etika individual adalah prinsip integritas pribadi. Perilaku ini untuk menjaga dan mempertahankan nama baiknya sebagai pribadi moral; (2) etika sosial, yaitu mengenai kewajiban dan hak, sikap dan pola perilaku manusia sebagai makhluk sosial dalam interaksinya dengan sesama. Etika individual dan etika sosial berkaitan antara satu sama lainnya, karena kewaijban seseorang terhadap dirinya berkaitan langsung dan dalam banyak hal mempengaruhi kewajibannya terhadap orang lain; (3) etika lingkungan hidup, yaitu etika mengenai hubungan antara manusia baik sebagai individu maupun kelompok dengan lingkungan alam.

Pengenalan ketiga macam etika tersebut sangat berkaitan dalam kehidupan dan seharusnya ditanamkan sejak usia dini. Kalau anak jalanan dibiarkan berkembang jumlahnya, negara akan rusak, rusak dirinya sendiri, rusak sosial dan rusak lingkungan alamnya.

Hal ini didukung oleh psikolog Bimo Walgito (1989) yang mengutip teori Pavlov, Thorndike dan Skinner Hergenhahn (1976) bahwa sebagian besar perilaku manusia adalah perilaku yang dibentuk, perilaku yang dipelajari. Selanjutnya perilaku yang dibentuk ada tiga cara yaitu (a) cara pembentukan perilaku dengan kondisioning atau kebiasaan, yaitu cara membiasakan diri untuk berperilaku seperti yang diharapkan, misalnya membiasakan bangun pagi, (b) pembentukan perilaku dengan pengertian, yaitu perilaku yang dibentuk dengan adanya pengertian, misalnya tidak boleh datang terlambat karena mengganggu teman lain, (c) perilaku dengan menggunakan model, yaitu perilaku dengan mencontoh orang lain atau idolanya, misalnya ingin berperilaku seperti ayahnya, atau pemimpinnya.

\section{METODOLOGI PENELITIAN}

Penelitian ini menggunakan desain penelitian survei untuk menggali informasi tentang keberadaan anak jalanan di Kota Madiun dan pemberian angket untuk mengetahui data pribadi serta etika mereka yang selama ini bersama teman-teman anak jalanan lainnya. Selain survei dilakukan wawancara untuk memperoleh informasi lebih lengkap tentang diri anak jalanan. Selanjutnya peneliti memberi wawasan tentang pendidikan etika dengan harapan anak-anak tersebut akan tergugah hatinya tentang kehidupan yang harus dijalani sesuai norma dan tanggungjawab masa depan. Peneliti berkoordinasi dengan Dinas Sosial dan satpol PP Kota Madiun agar usaha ini membuahkan hasil yang baik. 
Populasi dalam penelitian ini adalah semua anak jalanan yang kegiatannya di perempatan jalan dan juga hasil razia Satpol PP Kota Madiun tahun 2011 berdomisili di Kota Madiun yang telah dicatat oleh Dinas Sosial Kota Madiun sebanyak 24 anak sebagai responden. Menurut Sringarimbun (1987) bahwa populasi tersebut termasuk secara sempurna tidak seragam (completely heterogenous), maka hanya pencacahan lengkaplah yang dapat memberikan gambaran yang representatif. Oleh sebab itu, yang menjadi sampel penelitian, peneliti mengambil semua anak jalanan yang telah tercatat di Dinas Sosial Kota Madiun tahun 2011 dan berdomisili di Kota Madiun sebanyak 24 anak.

Data yang dikumpulkan dalam penelitian ini adalah data primer dan data sekunder. Data primer diperoleh dari kuesioner dan hasil wawancara kepada responden. Data primer berupa hasil angket yang diisi oleh anak jalanan yang sudah terdaftar di Dinas Sosial sebanyak 24 anak sebagai responden. Peneliti menyampaikan angket kepada responden ke rumah-rumah sesuai alamatnya yang dicatat oleh Dinas Sosial untuk diisi. Kemudian dilakukan wawancara untuk menambah kelengkapan masukan dari anjal. Selain itu menyampaikan undangan untuk menghadiri pertemuan yang akan diadakan pada waktu dan tempat yang telah ditentukan untuk diberi penyuluhan tentang pendidikan etika. Data sekunder berupa gambaran Kota Madiun, luas wilayah, jumlah Penduduk, kepadatan penduduk, mata pencaharian, dan pendidikan diperoleh dari dokumen Madiun dalam Angka (2011). Data yang terkumpul berupa data primer yang terdiri dari angket dan hasil wawancara dari anak jalanan serta data sekunder berupa jumlah penduduk, kepadatan penduduk, mata pencaharian dan lain-lain, dianalisis secara deskriptif kualitatif.

\section{Hasil Penelitian dan Pembahasan Hasil Penelitian}

Kota Madiun adalah daerah tingkat dua di Provinsi Jawa Timur yang terletak pada $1110 \mathrm{BT}$ 1120BT dan 70LS-80LS. Wilayah Kota Madiun berada di tengah atau di kelilingi wilayah Kabupaten Madiun. Sebelah utara berbatasan dengan Kecamatan Madiun, sebelah selatan berbatasan dengan Kecamatan Geger, sebelah timur berbatasan dengan Kecamatan Wungu, dan sebelah barat berbatasan dengan Kecamatan Jiwan.

Luas wilayah kota Madiun 33,23 km2, terbagi menjadi 3 kecamatan, yaitu Kecamatan Manguharjo dengan luas wilayah 10,04 km2, Kecamatan Taman 12,45 km2, dan Kecamatan Kartoharjo 10,73 km2, masing-masing kecamatan terdiri dari 9 kelurahan, jadi Kota Madiun mempunyai 27 kelurahan. Tinggi daratan wilayah kota Madiun rata-rata adalah 65 meter di atas permukaan air laut. Keadaan iklimnya, sepanjang tahun 2010 hampir tiap hari hujan. Pada bulan Agustus hujan tidak turun sama sekali. Dalam satu bulan rata-rata terdapat 20 hari hujan dengan curah hujan rata-rata $229 \mathrm{~mm}$. Hari hujan terbanyak pada bulan Mei dengan curah hujan tertinggi $413 \mathrm{~mm}$.

Jumlah penduduk Kota Madiun menurut sensus 2010 adalah 170.964 jiwa, adapun kepadatan penduduknya adalah 5.145 orang per km2 seperti pada Tabel 2.

Kota Madiun terdiri dari tiga kecamatan yaitu Kecamatan Manguharjo, Kecamatan Taman dan Kecamatan Kartoharjo. Dari tiga kecamatan tersebut yang paling banyak penduduknya adalah Kecamatan Taman sebanyak 72.667 orang, kepadatan penduduknya 4919 dengan luas wilayah $12,46 \mathrm{~km} 2$, sedangkan yang paling sedikit penduduknya adalah Kecamatan Kartoharjo sebanyak 48.906, kepadatan penduduknya 4558 dengan luas wilayah $10,73 \mathrm{~km} 2$. 
Tabel 2. Jumlah Penduduk Kota Madiun Tahun 2010

\begin{tabular}{lcrrrr} 
Kecamatan & \multicolumn{2}{c}{ Luas Area } & \multicolumn{2}{c}{$\begin{array}{c}\text { Jumlah Total } \\
\text { Penduduk }\end{array}$} & Populasi \\
& $(\mathrm{Km} 2)$ & \multicolumn{1}{c}{$\%$} & Orang & $\%$ & \\
\hline Manguharjo & 10,04 & 30,21 & 49.391 & 28,89 & 4919 \\
Taman & 12,46 & 37,50 & 72.667 & 42,50 & 5832 \\
Kartoharjo & 10,73 & 32,29 & 48.906 & 28,61 & 4558 \\
\hline Total & 33,23 & 100,00 & 170.964 & 100,00 & 5145 \\
\hline
\end{tabular}

Sumber, Madiun dalam angka, 2011

Keadaan pendidikan di kota Madiun cukup maju, terbukti dengan adanya jumlah sekolah dari tingkat Taman Kanak-kanak (TK) hingga Sekolah Lanjutan Tingkat Atas (SLTA) cukup memadai. Bahkan jumlah sekolah TK dan SD pada tahun 2010 bertambah seiring semakin banyaknya jumlah murid. Demikian juga dengan jumlah guru sebagai tenaga pengajarnya telah mencukupi, sehingga rasio murid-guru yang ideal untuk semua tingkat sekolah dapat tercapai.

Selain meningkatkan sarana dan prasarana pendidikan, Pemerintah Kota Madiun melalui Dinas pendidikan, Kebudayaan, Pemuda dan Olahraga menyelenggarakan program keaksaraan fungsional. Program ini bertujuan untuk mengurangi angka buta aksara di Kota Madiun. Setiap tahun peserta program ini bertambah. Pada tahun 2009 jumlah pesertanya 230 orang. Jumlah ini sesungguhnya masih jauh dari yang ditargetkan, yaitu 600 orang.

Tabel 3. Nama-nama Anjal Kota Madiun Tahun 2011

\begin{tabular}{lccl}
\multicolumn{1}{c}{ Nama } & Lulus & Lulus & \multicolumn{1}{c}{ Keterangan } \\
& SD & SMP & \\
\hline Andika & $\sqrt{ }$ & - & Kelas 3 SMP \\
Joko Prasetyo & $\sqrt{ }$ & $\sqrt{ }$ & \\
Agus Trilaksono & $\sqrt{ }$ & - & \\
Wiwik & - & - & Kelas 5 SD \\
Ajep Sakumala & $\sqrt{ }$ & - & Kelas 1 SMP \\
Ignatius Restu A & $\sqrt{ }$ & - & Kelas 1 SMP \\
Dwi Yuni Asmoro & - & - & Kelas 5 SD \\
Putri Prasetyowati & - & - & Kelas 2 \\
Topas Setyoyudo & $\sqrt{ }$ & - & \\
David Purwanto & - & - & Kelas 2 SD \\
Dimas Pratama & - & - & Kelas 3 SD \\
Dona Tristanto & $\sqrt{ }$ & - & Kelas 3 SMP \\
Ferry Agam & $\sqrt{ }$ & - & Kelas 1 SMP \\
Januri & - & - & Kelas 1 SD \\
Sari Prihatin & - & - & Kelas 2 SD sekarang \\
Wihada Atama & $\sqrt{ }$ & $\sqrt{ }$ & \\
\hline
\end{tabular}

Prosedur penyampaian instrumen pada responden dapat disajikan sebagai berikut: berdasarkan nama dan alamat Anjal dari Dinas Sosial Kota Madiun, peneliti mencari nama-nama tersebut sesuai dengan alamatnya, kemudian memberikan angket yang diisi langsung oleh nama Anjal yang bersangkutan dan ada yang diisikan oleh peneliti sesuai dengan jawaban pertanyaan dari 
angket. Adapun nama-nama Anjal sesuai dengan data dari Kantor Dinas Sosial kota Madiun dan hasil pengisian angket maupun hasil wawancara peneliti dengan anak jalanan sebagaimana terlihat pada Tabel 3.

Data status pendidikan hasil dari angket dan wawancara, dari 16 anjal yang lulusan SD 7 orang, tidak lulus SD 7 orang, lulus SMP 2 orang. Anak-anak ini waktu ditanya apakah masih ingin sekolah?

Jawabnya dia ingin kerja saja, tidak ingin sekolah lagi. Pada umumnya orang tua mereka tidak mempunyai beaya untuk menyekolahkan anak. Selain itu, karena terpengaruh temannya untuk tidak sekolah.

Tabel 4. Penghasilan Rata-rata per hari ANJAL 2011 Dan Penggunaannya

\begin{tabular}{lcl}
\hline \multicolumn{1}{c}{ Nama } & $\begin{array}{c}\text { Penghasilan } \\
\text { (rupiah) }\end{array}$ & \multicolumn{1}{c}{ Penggunaan } \\
\hline Andika & 30.000 & Untuk keperluan sendiri dan ibunya \\
Joko Prasetyo & 20.000 & Untuk keperluan sendiri dan ibunya \\
Agus Trilaksono & 10.000 & Untuk orangtua \\
Wiwik & 20.000 & Untuk keperluan sendiri \\
Ajep Sakumala & 20.000 & Untuk keperluan sendiri \\
Ignatius Restu A & 15.000 & Untuk keperluan sendiri \\
Dwi Yuni Asmoro & 10.000 & Untuk ibunya \\
Putri Prasetyowati & 20.000 & Untuk sendiri dan orangtua \\
Topas Setyoyudo & 20.000 & Untuk sendiri dan orangtua \\
David Purwanto & 50.000 & Untuk keperluan sendiri \\
Dimas Pratama & 30.000 & Untuk keperluan sendiri \\
Dona Tristanto & 20.000 & Untuk keperluan sendiri \\
Ferry Agam & 20.000 & Untuk keperluan sendiri \\
Januri & 20.000 & Untuk keperluan sendiri \\
Sari Prihatin & 15.000 & Untuk keperluan sekolah \\
Wihada Atama & 40.000 & Untuk keperluan sendiri dan orangtua \\
\hline
\end{tabular}

Ada 3 anak yang keterbelakangan mental yaitu Putri Prasetyowati, Dimas Pratama serta David Purwanto. Putri sekarang menjaga parkir sepeda di Supermarket JI. Urip Sumoharjo, Dimas sudah tidak mengamen, sedangkan David Purwanto masih minta-minta di alun-alun Madiun.

Hasil perolehan mengamen bervariasi, berupa uang, ada yang ngasih rokok atau permen. Apabila dihitung uang perolehannya rata-rata perhari ada yang Rp.10.000 sebanyak 2 orang, yang memperoleh Rp.15.000 sebanyak 2 orang, yang memperoleh Rp.20.000 sebanyak 8 orang, yamg memperoleh Rp.30.000 sebanyak 2 orang, yang memperoleh Rp.40.000 sebanyak 1 orang dan yang memperoleh Rp.50.000 sebanyak 1 orang.

Perolehan mengamen paling tinggi adalah Rp. 50.000, diperoleh oleh David Purwanto. Anak ini tidak mengamen, tetapi minta-minta saja di alon-alon Madiun. Anaknya hanya menempuh pendidikan sampai kelas 2 SD saja termasuk keterbelakangan mental.

Dari hasil mengamen yang bervariasi ini yang dipakai untuk keperluan sendiri sebanyak 9 orang, satu di antaranya untuk keperluan sekolah karena masih sekolah kelas $2 \mathrm{SD}$, sedangkan khusus untuk keperluan orang tuanya 2 orang dan untuk keperluan sendiri dan orangtua sebanyak 5 orang. 
Uang yang dipakai untuk keperluan sendiri pada umumnya dibelikan jajan, minuman, minuman keras bersama teman-temannya. Seperti Ferry Agam, pada waktu ditemui peneliti dia bersama 2 orang temannya menikmati minuman es sirup dan minuman keras/arak. Hal ini kelihatannya sudah menjadi kebiasaan, dilakukan di rumahnya sendini, orangtua tidak berani melarang.

Tabel 5. Pekerjaan Orang Tua Anjal 2011 di Kota Madiun

\begin{tabular}{|c|c|c|}
\hline Nama Anjal & Nama Orangtua & Pekerjaan \\
\hline Andika & Hadi Sumanto/Katiyem & $\begin{array}{l}\text { Ayahnya Swasta/ Ibunya kerja membantu rumah } \\
\text { tangga. Andika sekarang kerja di mebeler. }\end{array}$ \\
\hline Joko Prasetyo & Kasmanto/Murti & $\begin{array}{l}\text { Ayahnya Tukang Becak,/lbunya sakit struk, tidak bisa } \\
\text { jalan Joko sekarang kerja ikut bangunan, tapi } \\
\text { kadang-kadang masih ngamen. }\end{array}$ \\
\hline Agus Trilaksono & Slamet/Misri & $\begin{array}{l}\text { Ayahnya kerja srabutan, lbunya kerja di Loundry } \\
\text { mulai pagi sampai jam } 18.00 \text {. Agus sekarang kerja di } \\
\text { persewaan terop. }\end{array}$ \\
\hline Wiwik & Sudarsono/Munawaroh & $\begin{array}{l}\text { Orangtua di Mojokerto, Wiwik diserahkan ke lbu } \\
\text { Djinem yang juga pengamen. Wiwik pernah kerja } \\
\text { membantu di warung Maospati, tetapi sekarang } \\
\text { keluar, ngamen lagi. }\end{array}$ \\
\hline Ajep Sakumala & $\begin{array}{l}\text { Gandi Yulianto/Anik } \\
\text { Rochiani (cerai) }\end{array}$ & $\begin{array}{l}\text { Ayahnya kerja di gilingan daging Jl. Cempaka, } \\
\text { Ibunya pulang ke rumah orangtuanya. Adiknya kelas } \\
2 \text { SD ikut ibunya di Jl. Muria. Ajip tidak mengamen } \\
\text { lagi, masih cari kerja. }\end{array}$ \\
\hline Ignatius Restu A & Priyatno/Sutiah & $\begin{array}{l}\text { Bapaknya tukang becak, ibunya kerja membantu } \\
\text { rumah tangga, Restu pernah kerja ikut orang jualan } \\
\text { mi dan nasi goreng surungan keliling, tetapi penjual } \\
\text { tersebut tidak jualan lagi, restu juga tidak kerja } \\
\text { sampai sekarang dan tidak mengamen lagi }\end{array}$ \\
\hline Dwi Yuni Asmoro & Jumari (alm)/Jumirah & $\begin{array}{l}\text { Ibunya kerja membantu rumah tangga, Dwi Asmara } \\
\text { tidak ngamen dan juga belum dapat kerjaan. }\end{array}$ \\
\hline Putri Prasetyowati & Hadi Salim/Sumarti & $\begin{array}{l}\text { Ayahnya tukang becak, ibunya jualan nasi di warung. } \\
\text { Rumahnya digusur mau dibangun. Putri sekarang } \\
\text { tidak ngamen, kerja sebagai parkir sepeda di } \\
\text { Suppemarket Jl. Urip Sumoharjo. }\end{array}$ \\
\hline Topas Setyoyudo & Musafah/Dwi Hariyani & $\begin{array}{l}\text { Ayahnya kerja serabutan, ibunya jualan mracang di } \\
\text { rumah. Topas tidak ngamen lagi, kerja waktu sore } \\
\text { mengambil sisa-sisa makanan di RSU disetorkan } \\
\text { kepada peternak bebek. }\end{array}$ \\
\hline David Purwanto & Lasimun/Ismiyati & $\begin{array}{l}\text { Ayahnya juga minta-minta di wilayah Magetan. David } \\
\text { juga minta-minta di alon-alon Madiun. }\end{array}$ \\
\hline Dimas Pratama & Darwan/Sri Yuliati & $\begin{array}{l}\text { Ayahnya asli Jakarta, kena PHK, sekarang ikut } \\
\text { isterinya di Madiun bekerja serabutan, ibunya } \\
\text { membantu rumah tangga. }\end{array}$ \\
\hline
\end{tabular}


Tabel 4. Lanjutan

\begin{tabular}{ll} 
Nama Anjal & Nama Orangtua \\
\hline Dona Tristanto & Mujiono/Misiyam \\
Ferry Agam & Sutrisno/Sri Wahyuti \\
Januri & B Marem
\end{tabular}

Sari Prihatin Djainem (Cerai)

Wihada Atama
Wagiran/Sri Astuti
Pekerjaan

Pekerjaan orang tuanya serabutan. Doni adalah anak kembar, kembarannya melanjutkan di SMA. Doni sekarang kerja di tempatnya Pak Tohir penjual panggang ayam Tawangrejo.

Ayahnya kerja swasta, ibunya menerima pesanan masakan dan kue.

Dulu ibunya juga ngamen, sekarang kerja membantu rumah tangga di Dumai. Adiknya satu perempuan, keterbelakangan mental, hanya tidur saja. Seharian Januri setelah ngamen, uangnya dipakai untuk kegiatan playsteson.

Ibunya juga ngamen di Magetan, Sari juga masih ngamen setelah sekolah atau sore hari di alon-alon Madiun

Orangtuanya kerja serabutan, Wihada masih ngamen ikut Bus antar kota.

Dari 24 Anjal yang terdaftar di Kantor Dinas Sosial Kota Madiun, hanya 16 yang masih bisa dihubungi dan berdomisili di Madiun, sedangkan yang lainnya seperti Eko Priyo Utomo, sekarang ikut buliknya di Sumatera, ayahnya telah meninggal. Ego pergi ke Surabaya, orang tuanya cerai. Doni ke Surabaya, Renty Arista pindah ke Kediri, Rico adalah anak yatim piatu, tidak bisa dihubungi, menurut informasi orang yang pernah diikuti, Rico kerja di penjual Soto Madura Jl. Kapuas.

Ditinjau dari tempat tinggalnya, ada beberapa yang berdekatan rumahnya, jadi mereka dipengaruhi oleh temannya tersebut. Beberapa Anjal kalau ditanya kenapa mengamen, jawabnya karena ikut-ikutan.

Berdasarkan pengamatan langsung dari rumah ke rumah mencari alamat Anjal yang terdaftar di Dinas Sosial tahun 2011, maka penulis dapat menyimpulkan bahwa keadaan sosial ekonomi orangtua Anjal pada umumnya memprihatinkan, mereka kurang beruntung. Kehidupannya jauh di bawah standar kelayakan.

Pekerjaan orangtua mereka bervariasi, ayahnya ada yang menjadi tukang becak, tukang/kuli, serabutan, dan ada yang meminta-minta. Ibunya ada yang membantu rumah tangga, jualan nasi di warung, pegawai laundry, dan masih ada yang meminta-minta/pengemis.

Berdasarkan hasil pengisian angket, pada umumnya orangtuanya tidak menyuruh anaknya menjadi pengamen, sebagian besar dia ngamen karena kemauan sendiri ikut-ikutan temannya. Bahkan ada yang disuruh sekolah oleh orangtuanya tidak mau, seperti Ferry Agam. Dia lebih suka kebebasan daripada sekolah.

Setelah Anjal kena razia dari satpol PP Kota Madiun, mereka pada umumnya masih ngamen tetapi ganti tempatnya. Oleh sebab itu, Satpol PP terus menertibkan agar tidak ada lagi pengamen terutama di perempatan jalan. Bagi pengamen di bus, masih tergolong aman karena selama ini belum ada yang tidak memperbolehkan ngamen di bus, yang jangkauannya lebih jauh yaitu Madiun ke Surabaya dan Madiun ke Yogyakarta.

Langkah selanjutnya setelah data Anjal terkumpul, peneliti mengundang Anjal berkumpul di suatu tempat untuk diberi pengarahan tentang pendidikan etika oleh Dinas Satpol PP dan Dinas 
Sosial. Adapun isi peraturannya berkaitan dengan Anjal untuk menjaga ketenteraman dan ketertiban umum di daerah, siapapun dilarang untuk:

a. Mengamen, meminta-minta dan berjualan di sekitar lampu lalu lintas (traffic light).

b. Memberi uang atau dalam bentuk apapun kepada pengamen, pengemis maupun anak jalanan di sekitar lampu lalu lintas (traffic light).

c. Mengamen di tempat-tmpat makan, warung, depot dan rumah makan yang dapat mengganggu pengunjung kecuali disediakan tempat untuk mengamen.

d. Meminta-minta di tempat makan, warung, depot dan rumah makan yang dapat mengganggu pengunjung.

Selain peraturan tentang mengamen dan meminta-minta, masih banyak lagi dibacakan dan dijelaskan peraturan-peraturan lain yang sifatnya untuk umum, misalnya tentang mendirikan bangunan di tepi dan atau di atas jalan umum, saluran air dan fasilitas umum, menyimpan atau menjemur barang-barang yang menimbulkan bau busuk dan dapat mengganggu kesehatan dan sebagainya.

Oleh sebab itu, dihimbau untuk tidak mengamen di tempat-tempat yang dilarang oleh pemerintah setempat. Dijelaskan pula bahwa Satpol PP akan terus berusaha mentertibkan peraturan dengan patroli keliling setiap saat baik siang maupun malam dengan tujuan agar tercipta kondisi yang betul-betul aman dan nyaman.

Setelah pengarahan Tata Tertib oleh Dinas Satpol PP, dilanjutkan pengarahan dari Dinas Sosial yang menyatakan bahwa mengamen itu mengganggu ketertiban umum. Dinas Sosial akan menyalurkan kerja dengan membekali keterampilan sesuai yang diminati oleh Anjal. Ada beberapa macam pelatihan yang akan diselenggarakan oleh Dinas Sosial antara lain otomotif, elektro, sablon, memasak/Tata Boga dan lain-lain. Adapun tempatnya di Jl. Srindit. Peserta dibatasi umurnya maksimal 19 tahun.

Tabel 5. Nama Anjal dan Keterampilan yang Diminati

\begin{tabular}{ll}
\hline Nama & Keterampilan yang diminati \\
\hline Andika & - (tidak hadir) \\
Joko Prasetyo & otomotif \\
Agus Trilaksono & otomotif \\
Wiwik & Tata Boga \\
Ajep Sakumala & Sablon \\
Ignatius Restu A & Tata Boga \\
Dwi Yuni Asmoro & Sablon \\
Putri Prasetyowati & Tata Boga \\
Topas Setyoyudo & - (tidak hadir) \\
David Purwanto & Sablon \\
Dimas Pratama & Sablon \\
Dona Tristanto & Tata Boga \\
Ferry Agam & -(tidak hadir) \\
Januri & Sablon \\
Sari Prihatin & - (masih sekolah) \\
Wihada Atama & Otomotif \\
\hline
\end{tabular}


Masing-masing Anjal ditanya keterampilan apa yang disukai, dan masing-masing dicatat oleh Dinas Sosial. Adapun hasil penawaran keterampilan adalah seperti pada Tabel 5.

Dinas Sosial menjanjikan dalam waktu dekat akan menginformasikan waktu pelaksanaan pelatihan keterampilan tersebut.

Menurut petugas Dinas Satpol PP yang menangani Anjal, selama ini belum pernah melakukan pemberian wawasan pengetahuan tentang pendidikan etika. Selain itu juga belum pernah mengundangnya untuk berkumpul, memberi pengarahan. Yang penting sudah tercatat identitasnya sewaktu-waktu ada pelatihan seperti yang diadakan di Kota Malang, langsung mencari orang yang bersangkutan ke alamatnya. Pelatihan yang diberikan berupa keterampilan sekaligus disisipkan materi etika.

\section{Pembahasan}

\section{Faktor-faktor yang menyebabkan banyaknya Anjal di Kota Madiun}

Berdasarkan data-data hasil penelitian tentang Pendidikan Etika Anjal di Kota Madiun dengan menggunakan angket, wawancara serta observasi dari masing-masing Anjal sesuai dengan data dari Dinas Sosial, maka dapat ditinjau dari beberapa sudut pandang antara lain:

a. Status pendidikan Anjal.

Data status pendidikan hasil dari angket dan wawancara, dari 16 anjal yang lulusan SD 7 orang, tidak lulus SD 7 orang, lulus SMP 2 orang. Anak-anak ini waktu ditanya apakah masih ingin sekolah? Jawabnya dia ingin kerja saja, tidak ingin sekolah lagi. Pada umumnya orang tua mereka tidak mempunyai biaya untuk menyekolahkan, selain itu karena terpengaruh temannya untuk tidak sekolah.

Ada 3 anak yang keterbelakangan mental yaitu Putri Prasetyowati, Dimas Pratama serta David Purwanto. Putri sekarang menjaga parkir sepeda di Supermarket JI. Urip Sumoharjo, Dimas sudah tidak mengamen dan tidak bekerja, sedangkan David Purwanto masih minta-minta di Alonalon Madiun. Mulai siang jam 12.00 sampai jam 21.00. Bapaknya mengamen di Kab. Magetan setiap hari, minggu istirahat di rumah.

b. Penghasilan rata-rata

Penghasilan rata-rata per hari perolehan mengamen bervariasi, berupa uang, ada yang ngasih rokok atau permen. Apabila dihitung uang perolehannya rata-rata perhari ada yang Rp.10.000 sebanyak 2 orang, yang memperoleh Rp. 15.000 sebanyak 2 orang, yang memperoleh Rp.20.000 sebanyak 8 orang, yamg memperoleh Rp. 30.000 sebanyak 2 orang, yang memperoleh Rp.40.000 sebanyak 1 orang dan yang memperoleh Rp.50.000 sebanyak 1 orang.

Perolehan mengamen paling tinggi adalah Rp. 50.000, diperoleh oleh David Purwanto. Anak ini tidak ngamen, tetapi minta-minta saja di alun-alun Madiun. Anaknya David Purwanto hanya menempuh pendidikan sampai kelas 2 SD saja dan anak tersebut memiliki keterbelakangan mental.

Dari hasil mengamen yang bervariasi ini yang dipakai oleh anak untuk keperluan sendiri sebanyak 9 orang, satu di antaranya untuk keperluan sekolah karena masih sekolah kelas 2 SD. Khusus untuk keperluan orang tuanya 2 orang dan untuk keperluan sendiri dan orangtua sebanyak 5 orang.

Uang yang dipakai untuk keperluan anak sendiri pada umumnya untuk dibelikan jajan, rokok, minuman, dan minuman keras yang dilakukan bersama teman-temannya. Seperti Ferry Agam, pada waktu ditemui peneliti dia bersama 2 orang temannya menikmati minuman es sirup dan minuman keras/arak. Hal ini kelihatannya sudah menjadi kebiasaan, dilakukan di rumahnya sendiri, orangtua tidak berani melarang. 


\section{c. Pekerjaan Orang tua Anjal \\ Berdasarkan pengamatan langsung dari rumah-ke rumah mencari alamat Anjal yang} terdaftar di Dinas Sosial tahun 2011, maka penulis dapat menyimpulkan bahwa keadaan sosial ekonomi orangtua Anjal pada umumnya memprihatinkan, mereka kurang beruntung. Kehidupannya jauh di bawah standar kelayakan.

Pada umumnya anak-anak jalanan bertempat tinggal serumah dengan orangtuanya. Jadi menurut hasil seminar di Manila tahun 1989 tentang Anak jalanan termasuk kelompok pertama yaitu Children who maintainreguler contacts with their families yaitu kelompok anak jalanan yang masih mempunyai kontak langsung dengan orangtuanya. Jadi penanganannya secara prevention melalui pendidikan dari keluarga, misalnya orangtua diberi modal untuk berjualan, maka anaknya bisa diajak membantunya, atau anaknya kena razia oleh Satpol PP, maka orangtuanya yang dipanggil untuk mengambil anaknya tersebut ke kelurahan atau ke kantor Satpol PP, selanjutnya orangtua juga menasehati anaknya agar tidak mengamen lagi.

Data yang diperoleh dari pengisian angket dan juga wawancara, pekerjaan orangtua mereka bervariasi. Ayahnya ada yang menjadi tukang becak, tukang/kuli, serabutan, dan ada yang memintaminta. Sementara ibu-ibunya ada yang membantu rumah tangga, jualan nasi di warung, pegawai laundry, dan juga masih ada yang meminta-minta/pengemis.

d. Peraturan Daerah nomor 8 tahun 2006

Pelaksanaan Perda nomor 8 tahun 2006 berlaku pada tahun 2011. Adapun isinya yang berkaitan dengan Anjal adalah untuk menjaga ketenteraman dan ketertiban umum di daerah siapapun dilarang untuk:

1. mengamen, meminta-minta dan berjualan di sekitar lampu lalu lintas (traffic light)

2. memberi uang atau dalam bentuk apapun kepada pengamen, pengemis maupun anak jalanan di sekitar lampu lalu lintas (traffic light)

3. mengamen di tempat-tempat makan, warung, depot dan rumah makanyang dapat mengganggu pengunjung kecuali disediakan tempat untuk mengamen.

4. meminta-minta di dalam tempat- tempat makan, warung, depot dan rumah makan yang dapat mengganggu pengunjung.

Penertiban Perda ini ditangani oleh Dinas Satpol PP yang melibatkan banyak personil karyawannya. Sasarannya perempatan jalan, pertokoan, dan rumah makan. Sementara itu pengamen di kampung-kampung masih diberi toleransi artinya masih diperbolehkan mengamen. Selain di kampung-kampung, pengamen di terminal bus Madiun juga masih ada, namun jumlahnya tinggal sedikit. Pengamen yang mengikuti bus juga masih aman, mereka belum kena penertiban.

e. Penanganan dari Dinas Sosial

Penanganan dari Dinas Sosial selama ini menyalurkan kegiatan-kegiatan keterampilan. beberapa Anjal secara bertahap pergi ke Malang kurang lebih selama dua minggu. Mereka dilatih keterampilan misalnya memasak, otomotif, nyablon dan lain-lain sesuai dengan pilihan Anjal. Mereka dibekali pengetahuan dan keterampilan dengan harapan dapat menerapkan sendiri setelah selesai pelatihan. Beberapa Anjal yang telah mengikuti pelatihan dapat menciptakan lapangan kerja sendiri dan ada yang belum dapat memanfaatkannya. Hal ini tergantung dari kemauan, maupun biaya sebagai modalnya.

Dari beberapa uraian tentang status pendidikan Anjal, penghasilan mengamen per hari dan penggunaannya serta pekerjaan orang tua Anjal, maka dapat disimpulkan bahwa anak-anak tersebut adalah dari keluarga yang tidak mampu dan berpendidikan rendah. Selain itu ada beberapa keluarga yang berantakan/cerai. Hal ini mengakibatkan keluarga yang tidak mempunyai cita-cita masa depan 
dan tidak mengurus keluarga yang berkualitas. Jadi faktor-faktor yang menyebabkan banyaknya Anjal di Kota Madiun adalah:

Keadaan sosial ekonomi keluarga yang rendah, pendidikan yang rendah, keluarga yang broken home/cerai.

\section{Bentuk penanganan Anjal yang telah dilakukan}

Usaha-usaha yang dillakukan adalah:

1. Diberi pengarahan oleh Satpol PP pada waktu kena razia (carukan) agar mereka tidak mengamen di tempat-tempat terlarang/kena denda sesuai dengan Perda yang berlaku.

2. Diadakan evaluasi dan pemantauan terhadap Anjal agar mereka secara pelan-pelan dapat meninggalkan kegiatan sebagai Anjal.

3. Diberi pelatihan berbagai keterampilan sesuai dengan pilihannya dan diberi modal dalam bentuk pinjaman dengan bunga lunak.

4. Memonitor dan memberi semangat dalam penerapan keterampilan yang telah diberikan atau dibinanya.

Penanganan tersebut belum terealisir sepenuhnya karena terbatasnya tenaga dan biaya serta kesadaran Anjal sendiri untuk mengubah nasib.

Pendidikan etika untuk anak jalanan yang telah disampaikan oleh peneliti memperoleh tanggapan yang positip. Beberapa etika yang menjadi pernyataan adalah: etika memilih makan yang bersih dan bergizi, menggunakan pakaian bersih dan rapi serta rambut tersisir disetujui oleh mereka sebanyak 16 orang $(100 \%)$, mereka pamit kepada orang tua atau saudara yang masih di rumah sebanyak 16 orang (100\%), apabila mengamen tidak diberi uang, mereka tidak marah-marah sebanyak 16 orang (100\%), apabila mengamen sendiri-sendiri setuju bergantian dan tidak keroyokan sebanyak 16 orang (100\%). Lagu yang dinyanyikan untuk ngamen adalah hafal dan enak didengar, mereka setuju pernyataan teresbut sebanyak 16 orang (100\%). Mereka tidak akan berkelahi dengan sesama teman pengamen apabila ada masalah, mereka setuju sebanyak 16 orang $(100 \%)$.

\section{KESIMPULAN DAN SARAN}

Keberadaan Anjal di Kota Madiun yang biasa mengamen di perempatan jalan sekarang sudah banyak berkurang karena kerja keras penertiban dari petugas Satpol PP dengan cara menjaga tempat-tempat yang biasa untuk mangkal para pengamen. Beberapa Anjal telah sadar untuk tidak mengamen lagi dan mulai bekerja untuk mendapatkan uang. Pekerja ada yang menjadi tukang parkir, bekerja di mebeler, tukang batu, rumah makan ayam panggang, mengantarkan sisa makanan dari RSU Madiun untuk makanan itik, ikut persewaan pasang terop, dan beberapa yang belum mendapatkan pekerjaan.

Pada umumnya Anjal di Kota Madiun masih serumah dengan keluarga, namun mereka berasal dari keluarga tidak mampu dan berpendidikan rendah. Pekerjaan orang tua mereka ada yang pengamen, tukang becak, tukang kayu, serabutan, berjualan kue gorengan, warung nasi, dan berjualan kecil-kecilan (warung meracang). Ada beberapa faktor penyebab banyaknya Anjal di Kota Madiun adalah keadaan sosial ekonomi keluarga yang rendah, pendidikan yang rendah, dan keluarga yang broken home/cerai.

Pengarahan dari Satpol PP Kota Madiun menegaskan bahwa mereka tidak boleh mengamen di perempatan jalan sesuai Perda nomor 8 tahun 2006 yang baru terlaksana tahun 2011. 
Pengarahan dari dinas Sosial mereka akan diberi pelatihan sesuai dengan minatnya, misalnya otomotif, tata boga dan sablon.

Pendidikan etika untuk Anjal yang telah disampaikan memperoleh tanggapan positip. Mereka semua menyatakan setuju atas beberapa etika, baik etika tentang menjaga kesehatan, etika waktu mengamen, etika waktu di jalan, etika waktu di tempat kerja, dan etika yang berkaitan dengan agama untuk menanamkan kepercayaan diri dan menghindari perilaku yang jahat, mencuri, menyakiti orang lain, dan berkelahi.

Agar anak kembali hidup normal di masyarakat, perlu penanganan serius setelah mereka kena razia dari Satpol PP. Bagi yang telah diberi pelatihan keterampilan, hendaknya ditindaklanjuti, diadakan evaluasi sampai benar-benar mereka dapat hidup mandiri. Perlu diadakan pertemuan 3 bulan sekali atau 6 bulan sekali untuk mendapatkan wawasan tentang etika supaya menjadi anak yang santun dan layak hidup bersama di masyarakat. Selain itu orang tua Anjal perlu mendapatkan perhatian atau perlakuan khusus dari pemerintah agar mendapatkan kehidupan layak, misalnya memberi modal untuk usaha, memberikan pelatihan/kursus menjahit, memasak, bengkel dan lain-lain beserta peralatannya.

\section{REFERENSI}

Badan Pusat Statistik dan Bappeda Kota Madiun. (2011). Kota Madiun dalam angka.

Departemen Pendidikan dan Kebudayaan1999. Kamus besar bahasa Indonesia. Jakarta: Balai Pustaka.

Kerap, Sony, A. (1998). Etika bisnis tuntutan dan relevansinya. Yogyakarta: Kanisius.

Magnis, Franz, \& Suseno. (2000). 12 Tokoh etika abat ke-20. Yogyakarta: Kanisius.

Peraturan Daerah Kota Madiun. Nomor 8 Tahun 2006.

Suyanto, B. (2003). Masalah sosial anak. Jakarta: Kencana Prenada Media Group. 